\title{
MARKETIZATION OF JAPAN-BASED HIGHER EDUCATION ADVERTISEMENTS: A DISCOURSE OF MCJOBS?
}

\author{
Mukaddam Khaitova ${ }^{1^{*}}$ \\ ${ }^{1}$ Toyama Prefectural University, Imizy, Toyama, Japan \\ Theron Muller ${ }^{2 * *}$ \\ ${ }^{2}$ University of Toyama, Gofuku, Toyama, Japan
}

\begin{abstract}
We investigate how competing forces interdiscursively manifest in Japanbased higher education through a critical discourse analysis (Fairclough, 1993, 1995). Higher education job advertisements are constitutive of institutions' public images that are targeted toward academics in specific fields. They are discursive spaces where marketized discourse has colonized previously dominant discourses of universities as independent authorities (Fairclough, 1993, 1995). Such marketized discourses within higher education express neoliberal ideologies and free-market conventions (Ball, 1998; Pack, 2018). However, the international extent of university discourse marketization is largely implicitly assumed rather than empirically examined, hence we investigate these forces with respect to Japanese higher education.

Keywords: marketization; metrification; academic job advertisements; Japan-based higher education; critical discourse analysis
\end{abstract}

\footnotetext{
" Part-time teacher of English at Toyama Prefectural University's Engineering Department. She studied at Novgorod Lyceum, Russia, graduating with an Honours Diploma degree in German Philology before serving 20 years at international organizations and diplomatic missions followed by teaching in Japan. Ms. Khaitova attended St Antony's College, Oxford, gaining an MPhil degree. Her research interests develop around alternative ways of teaching, online classroom, blended learning, collaborative and problem-based learning, and student-teacher relationships. E-mail: khaitova@pu-toyama.ac.jp. ORCID: https://orcid.org/0000-00021250-3487.

${ }^{*}$ Associate Professor at the University of Toyama, Japan. He received his doctorate from Open University in 2018, rand his research explored publication practices of Japan-based language teachers. He has published and presented widely on the topic of writing for academic publication, English language teaching and learning, and teacher development. He is active with JALT Publications and is a founding member of English Scholars Beyond Borders. E-mail: theron@las.u-toyama.ac.jp. ORCID: https://orcid.org/0000-0001-9690-3738.
} 


\section{Introduction}

Higher education's metrification trends are well-documented, with increasing use of characteristics as varied as publication outputs (Kuwayama, 2017), gender diversity (Wieczorek-Szymanska, 2020), and internationalization of universities (de Wit, 2009), to name but a few. Such metrification is representative of the colonization of higher education discourses by neoliberal marketized discourses, which prioritize viewing institutions as businesses answering to stakeholders (Teichler, 2004; Brown, 2011). Such ideologies jeopardize characterizations of the academic profession as exhibiting "shared ethical codes, values, and morals, altruistic missions, esoteric knowledge, intellectual supremacy, the intrinsic definition of qualifications, quality of work and new members and organized unions" (Pekkola et al., 2018, p. 137). Such trends have been documented within Anglophone universities (Nuttall et al., 2013; Gunn et al., 2015; Muller \& Skeates, forthcoming) and within European-based universities to a lesser extent (Askehave, 2007), with these universities used as proxies for the sector more broadly. However, it can be problematic to assume such trends have progressed equally more widely and that regional variation is not important (Muller \& Skeates, forthcoming). To explore this, here we investigate Japan-based higher education, examining the extent to which its job advertisements exhibit characteristics of marketization. Japan has experienced the transformations brought about by neoliberal marketized discourse in higher education to at least some extent (Mok, 2011; Brown, 2011). However, examinations of marketization of Japanbased higher education job advertisements remain relatively uncommon, except for Muller and Skeates (forthcoming). Thus, here we examine Japan-based higher education job advertisements to understand how neoliberal market-oriented discourses manifest in them. In this study, marketization is understood as a force that "challenges stakeholders with radical change encompassing issues of power, funding, labour, markets, and complexity" (Lowrie \& Hemsley-Brown, 2011, p. 1081) that reshapes and redefines the academic profession.

Japan-based higher education is of interest for three reasons. Firstly, it has been the subject of regular investigation via the Carnegie Foundation (Arimoto, 2011). Secondly, it has been described as largely "closed" (Hall, 1998, p. 7) to influences from outside of Japan, as it has traditionally resisted giving faculty from outside Japan status equal to their Japanese colleagues. Thirdly, while there are opinions concerning the internationalization of Japanese higher education (Yonezawa et al., 2009; Kuwayama, 2017), there remains little empirical research into how the forces of internationalization, conceived here specifically as forces of marketization and metrification, have influenced the sector and its discourses, with Hadley (2015) a notable exception. These characteristics point to a tension explored here: Japan-based higher education is used as a proxy for international higher education more broadly, although it has also been characterized as closed to those same forces, raising questions about it being an effective proxy. Furthermore, while the consensus appears to be that forces of marketization 
and metrification have advanced evenly across the sector, including in Japan, if Japanese higher education is indeed closed, then this may not be the case.

The metrification of higher education has proceeded across countries, institutions, departments, and individuals (Bauman \& Donskis, 2013). On the individual level, such metrics include impact factor and citation counts to evaluate faculty output. This leaves academics with "little time to think" (Pack, 2018, p. 122 ) as they pursue more publications, better presentations, and higher impact factors. Thus, numbers have replaced being thoughtful (Pack ,2018), with faculty positions increasingly reminiscent of fast-food work "McJobs" (Ritzer, 2018, p. 122) as quantitative indices prevail over qualitative, with evaluation focused on volume. For example, points-based annual faculty audits evaluate the number of outputs generated, such as journal articles, pushing trends toward publishing more and more frequently (Fire \& Guestrin, 2019). This is particularly prominent in modern universities' publish or perish cultures where faculty are "a (situational) somebody" with staff "no more than a CV and a series of figures" (Bauman \& Donskis, 2013, p. 158). Requirements can include 'dozens of publications and over a dozen of international conference presentations' (McCrostie, 2010, p. 121) to qualify for full-time positions, restricting access to upward career mobility and academic survival. When, "in hiring and promotion decisions, a résumé with a long list of articles and books is generally preferred to one with a shorter list" (Pack, 2018, p. 122), faculty are not regarded as constituting the university but rather as employees. Employees who, in their forced pursuit of numbers, are increasingly commodified, with quality subservient to requirements to be "more accountable to the administrators who are seeking ever more efficiency" (Pack, 2018, p. 122). One place where such metrification is made public in the discourse of universities is their job advertisements, which are public documents soliciting applications for open positions. As such, examining Japan-based university job advertisements can elucidate the extent to which their discourse reflects these trends.

\section{Review of Research into the Marketization of Higher Education}

We begin our review with themes related to the marketization of higher education, including the academic profession past and present, highlighting challenges reflecting neoliberal ideology's impacts. Next, we discuss the academic profession in Japan and challenges presented by marketization. Finally, we review critical discourse analysis (CDA) studies of academic job advertisements as an aspect of public higher education discourse constitutive of the public image institutions hope to cultivate. Notably, job advertisements have been documented as a discursive space where marketized discourse has colonized previously dominant discourses of universities as independent authorities (Fairclough, 1993, 1995).

Before discussing the discourse of Japanese higher education, it is first important to describe the characteristics of the academic profession more broadly. Here we identify three primary characteristics: specialization of individual academics into disciplines, an orientation toward research and teaching, and a 
competition of ideas. After this, we explain how neoliberal market ideologies' encroachment upend this previously stable balance of characteristics.

In pre-marketization and pre-neoliberal depictions of the academic profession, academics specialized into disciplines that were characterized by their own domain and knowledge base (Becher \& Trowler, 2001). Academics, therefore, were associated with their disciplines rather than their institutions (Becher \& Trowler, 2001; Teichler et al., 2013). Careers progressed from graduate study to professorship (Pekkola et al., 2018), delineating professional domains, with research and teaching-oriented institutional tasks (Reilly et al., 2016). Hence, the academic profession comprised different teaching or research 'occupational categor[ies]' (Teichler et al., 2013, p. 10). Thus, while disciplinary specialty subjects differ, their organizational characteristics unite them as an academic profession.

Disciplines' requirements were constructed through historical processes, including the need for thorough and continuous education followed by strenuous, slow-paced career advancement and competition of ideas. This is not to say that higher education in the past was a panacea. It was largely white male dominated and promoted colonization through encouraging exploration as economic opportunity by framing knowledge as vested in higher education rather than distributed throughout societies (Turner, 2011). Nevertheless, the academic profession associated with teaching and research, including a focus on reasoning and thought, where other crafts' tools could not be applied.

Marketization disrupted the framework described above (Teichler et al., 2013), instigating increasing isolation and separation within new corporate cultures. Notably, higher education is colonized by neoliberal 'ideologies of the market' (Ball, 1998, p. 122). Through introducing their own language and practices, these ideologies transform the profession to emphasize individual competition over the previous competition of ideas (Lowrie \& Hemsley-Brown, 2011). Such individual competition involves seeking access to limited resources among researchers and between departments within institutions. Furthermore, universities compete and the higher education sectors of different countries compete. Universities are, therefore, increasingly results-oriented as they "are run more like businesses" which "means that academics are more than ever judged on their productivity" (Pack, 2018, p. 122). Being results oriented involves "generating income through commercialized research [...] training rather than education, and [...] to more accurately assess efficiency" (Pack, 2018, p. 146) of academics. Academics are in turn required to constantly publish as "tenure track jobs are made less available in favor of administrators" (Pack, 2018, p. 146). This represents "the conversion of an educational system into a factory system" where "measures are adopted to more accurately assess efficiency" (Pack, 2018, p. 148), placing faculty in competition as opposed to the former competition of ideas, leading to increasing isolation. This represents the starting point for our investigation; a desire to unpack how these forces manifest in the university job advertisements examined here. 


\section{The Academic Profession in Japan}

As our investigation is concerned with representations of Japanese higher education within the discourse of its job advertisements, it is important to review Japanese higher education research. Japan-based higher education has been depicted as historically developing under principles of balance between teaching and research (Arimoto, 2011; Huang, 2015) with “a majority of Japan's academics" (Huang, 2015, p. 2) research-oriented. However, disjointed higher education reforms "almost every 15 years since the early 1950s" (Huang, 2014, p. 2) have changed this. Universities have been pressured to orient toward the neoliberal objectives of being more internationally and cross-institutionally competitive through competing for research funding and students as customers (Molesworth et al., 2011). Such pressure to change Japan-based universities' orientations in potentially incompatible ways has led to institutions fracturing into different, disparate orientations. As a result, Japan-based higher education bears "a clear division of labor between the national and private sectors" (Huang, 2015, p. 2), with $5 \%$ of faculty employed by "elite" (Teichler et al., 2013, p. 58) national research universities and $95 \%$ by teaching-oriented private universities (Yamamoto, 2012; Arimoto, 2011). While this division results in different orientations toward academics in universities (Yamamoto, 2012; Arimoto, 2011), the pressures they face share one overarching similarity: the need to demonstrate high productivity. Thus, numbers that grade and rank performance in terms of efficiency in publication and teaching have become prevalent through an "audit culture" (Kuwayama, 2017, p. 162) imported from business.

More broadly, Japan-based higher education is going through challenging times, pressured by a shrinking student population (Yamamoto, 2012; Watanabe et al., 2013; Huang, 2014) and an annual one percent reduction in universities' public funding (Huang, 2015). This intensifies tensions surrounding employment opportunities in the oversupplied job market (Watanabe et al., 2013). It also strains the market for foreign applicants, who regularly turn over as international faculty have historically been employed in adjunct positions (Hall, 1998; Rivers, 2013). Such turnover has been justified through a job market where fresh "nativespeaking" (Rivers, 2013, p. 77), "exotic" (Hall, 1998, p. 19) looking teachers are proffered to consumer-students. The job market for Japanese scholars is stiffened by internationalization and globalization, as the audit culture requires publishing in English outside of Japan (Kuwayama, 2017).

\section{Research on Academic Job Advertisements}

Here we review CDA studies of academic job advertisements informing this study. Starting with Fairclough's (1993) analysis of UK higher education job advertisements, we discuss how CDA reveals the blending of traditional university discourses and new discourses of marketization. Internationalization of higher education has been depicted as proceeding through an increasing 
incorporation of ideas and concepts from business, referred to as "marketization," which represents "academic capitalism, spreading compulsorily through bureaucratic governance and the destruction of the universities' autonomy and academic freedom" (Bauman \& Donskis, 2013, p. 138). We discuss such colonization of corporate discourse into academia through studies of academic job advertisements in China (Xiong, 2012; Feng, 2019); Australia (Nuttall et al., 2013) and Japan (Muller \& Skeates, forthcoming).

In a seminal study of three academic job advertisements, Fairclough (1993) exemplified the idea of universities steadily accepting the routine of 'rationality' (p. 139) where communication was steadily replaced by strategy. Although Fairclough does not differentiate the discourses of marketing as "promotional discourse" (p. 139) and marketization (the process of fastfoodization discussed above), his arguments concerning the colonization of universities' discourses have since been expanded. For example, Xiong (2012) examined 48 Chinese higher education job advertisements from a Chinese language newspaper between June 2009 and May 2011 circulated to Chinese expatriates. Xiong concludes the job advertisements' contents correspond to marketized discourse intended to reverse China's brain drain, attracting "academic star talents" (2012, p. 331) by highlighting attractive remuneration packages and promoting "future aspirations" (2012, p. 229). Xiong's study informs Feng (2019), another researcher into China who analysed 80 job advertisements on WeChat from August 2016 to September 2017. Feng finds, contrary to Xiong, more homogeneity and standardization in academic job requirements. Feng proposes that the online social space together with marketization and institutional policies generically refurbishes job advertisements, intensifying the admixture of moves, informative goals, and institutional representations. In other words, Xiong (2012) finds clearly delineated moves in newspaper advertisements. However, in the analysis of online data, Feng (2019) finds it to be more ambiguous, with communicative moves intermixed, making it difficult to determine clear genre patterns. Thus, while Xiong (2012) categorizes print advertisements into four types, Feng (2019) reveals more variation across posts. Moreover, the online job advertisements Feng analyses "accommodate more communicative functions as well as a large number of tables, graphs, and visual images" (p. 133), making them more informative than those analysed by Xiong.

Nuttall et al. (2013) studied 55 Australian teacher education job advertisements. Their review of "front end" (the text of advertisements promoting institutions) against the "back end" (2013, p. 334) (blueprints for desirable applicants) suggest that these two parts were disconnected. Finally, Muller \& Skeates (forthcoming) analysed 24 job advertisements collected between 2017 and 2019 for language teaching positions outside and inside Japan. Based on their comparative linguistic analysis of self-representations of institutions in the advertisements, they find Japanese universities' advertisements largely lack the discourse of marketization, contrary to earlier findings for the Chinese and Anglophone contexts reviewed above. 
The literature reviewed here mainly approaches marketization using a marketing or promotional (branding and self-branding) lens, examining the impact of such discourse on representations of higher education institutions and the academic profession. While these studies have shown aspects of marketization in university discourse, their focus on marketing as opposed to marketization means they may overlook the full impact of marketization on the sector's discourse. Thus, rather than examining only the marketized promotional features of university job advertisements, here we examine the discourse of marketization more broadly, presenting a fuller picture of how marketization, as opposed to marketing, transforms the sector's discourse. Therefore, we address a gap in conceptualizing marketization in the discourse analysis literature by viewing marketization as an ideology influencing representations of the academic profession through commodification, devaluation, and reconceptualization. Specifically, we examine the following research questions:

1. How does marketisation manifest in Japan-based higher education institutions' job advertisements? How do such representations compare across disciplines?

2. In what ways does commodification shape how the academic profession is represented?

3. What is the impact of interdiscursivity across disciplines?

Having reviewed discourse analysis investigations of academic job advertisements for their representations of professional practices and interactions, next we turn to our theoretical framework and methods of investigation.

\section{Methods}

\section{Theoretical Framework}

This study examines job advertisements to understand how the academic profession is represented in them using discourse analysis, which concerns the relationship between power and discourse (Foucault, 1972). Discourse here refers to "institutionally produced knowledge [as] a social rather than a linguistic category; [where] the social is taken as the generative 'source' of meaning' (Kress, 2012,p. 35). The terms 'discourse' and 'text' represent "'extended stretches of speech or writing' as well as pointing to the social meanings 'inherent' in such texts" (Kress 2012, p. 35). Within discourse analysis, CDA addresses social problems (Fairclough, 1993, 1995), and as our investigation is interested in such problems within higher education, it methodologically underpins the investigation. 


\section{Procedure}

This investigation uses CDA to examine questions of marketization, commodification, and interdiscursivity in Japan-based higher education job advertisements, as CDA uses social problems as a focus of analysis. For example, Fairclough's (1993) examination of higher education job advertisement discourses applies intertextuality, where discourses or texts are in dialogue. Specifically, CDA takes a perspective whereby:

1. texts are understood through their ideologically charged language,

2. discourses develop within the timespan, therefore understanding context is important,

3. broad and hybrid interpretations easily adapt and join new contexts, and

4. discourse represents social behaviour.

(Wodak, 1996)

CDA researchers are drawn to job advertisements for several reasons. First, they entextualize tensions between the different ideologies that shape them. Second, as they are texts created by and for specific contexts, examining them facilitates commenting on the contexts of their production. Third, hybridization (Fairclough, 1993), or mixing marketized language and the more traditional discourses of the academy (such as authority) is explorable (Askehave, 2010; Feng, 2019; Xiong, 2012). Finally, the social actors that comprise universities are examinable. Our analysis elucidates how the advertisements employ marketized discourse and are colonized by such discourse.

Consistent with other investigations of job advertisements (Feng, 2019; Muller \& Skeates, forthcoming; Xiong, 2012), we collected 81 online English language medium advertisements for jobs at Japan-based higher education institutions (Table 1), 75 direct hire and 6 dispatched. The advertisements were collected between July and November 2020, mainly from jREC-IN Portal (67 advertisements), a research career support site (Japan Science and Technology Agency 2020), the Japan Association of Language Teachers' (2020) job site (5 advertisements), jp.indeed.com (2020; 8 advertisements), and jobs.gaijinpot.com (2019; 1 advertisement). We categorized the advertisements by position type, collecting 25 each for part-time, full-time non-tenured, and full-time tenured positions, also consistent with how earlier researchers organized data for analysis (Muller \& Skeates, forthcoming). We originally planned to collect an equal number of outsourced and dispatched advertisements, but only found six during the collection period, and so that position type is underrepresented. Nevertheless, as previous studies have not examined dispatched job advertisements within higher education, we felt it important to include them. 
Following Muller and Skeates (forthcoming), our analysis was iterative and cyclical, beginning by analysing two advertisements from each category to identify their discourse characteristics. These initial observations were then iteratively tested against additional advertisements from each category, gradually developing a picture of the overall features of the different texts. Our analysis moved between the job advertisement texts, the literature analysing job advertisements, and the research questions.

Throughout our findings and discussion, when extracts are used, they are referenced to our dataset with an alphanumeric code, including position type as follows: PT: part-time adjunct, NT: non-tenured adjunct, TT: tenure-track, and OD: outsourced/dispatched (and adjunct). This is followed by the number format: YYYY-MM-DD-\# to indicate the date the advertisement was collected, and a number accounting more than one advertisement being collected per day. To illustrate, PT 2020-08-03-2 represents a part-time adjunct position, the second advertisement collected on August 3,2020. We focus on examining the job advertisements by position type rather than institution specific discourses and so do not identify institutions here.

\section{Findings: Features of the Higher Education Job Advertisements}

Our iterative, cyclical analysis identified the following three features of the advertisements relevant to our examination of the colonization of higher education discourses by neoliberal marketized discourses:

- Feature 1:

Titling The job position title in the advertisements

- Feature 2: Specifying the job and application requirements

Description of the job position, compulsory preconditions, and requirements to pass initial screening

- Feature 3: Research field

Potential institutional support for future publications

These features illustrate the heterogeneity of Japan-based higher education job advertisements as a space where different discourses vie for prominence. Various forces are represented here, including marketization, Anglicization and globalization, the prominence of teaching versus research, and other policy debates. The discourse of marketization intensifies:

1. commodification of work (Features 1 and 2);

2. explicit quantification and expectations for multitasking (Feature 2); 
3. commercialization and ranking applicants according to efficiency scales (Feature 3).

Within these three features there were more specific themes raised. Summary information is presented in Table 1 where the academic fields the advertisements represent are tracked along with some of the main points. Consistent with CDA expectations to present complete data, we have included a full, anonymized sample advertisement in Appendix 1. Feature 1 examines whether a position title reflects its type, such as PT or NT (Feature 1, Titling in Table 1). For example, we analyze whether for a part-time position the text "part-time" (PT 2020-08-11-14) appears in its title. There were other aspects of desired candidates signalled in some titles, such as "female" (TT 2020-08-05-1), which are tracked in the Other column. For Feature 2, a common requirement was that applicants were "native" speakers (Table 1, 2a). For example, "native English speaker" (PT 2020-08-1114). Another requirement was to document the number of publications (Table 1, 2b); except for dispatched positions, such advertisements required, for example, "reprints of representative publications"(NT 2020-08-14-12). For Feature 3, the main index was institutional research support through such terms as "research subsidy" (NT 2020-08-11-10). Features 1 and 2 tend to be explicitly referenced in the advertisements while Feature 3 tends to be more implicit. This is perhaps suggestive of Japan as a high-context culture (Hall, 1976) where information assumed to be understood is not elaborated, which we return to in our discussion.

Table 1 Basic Statistical Data for Type of Position, Discipline, and the Three Features

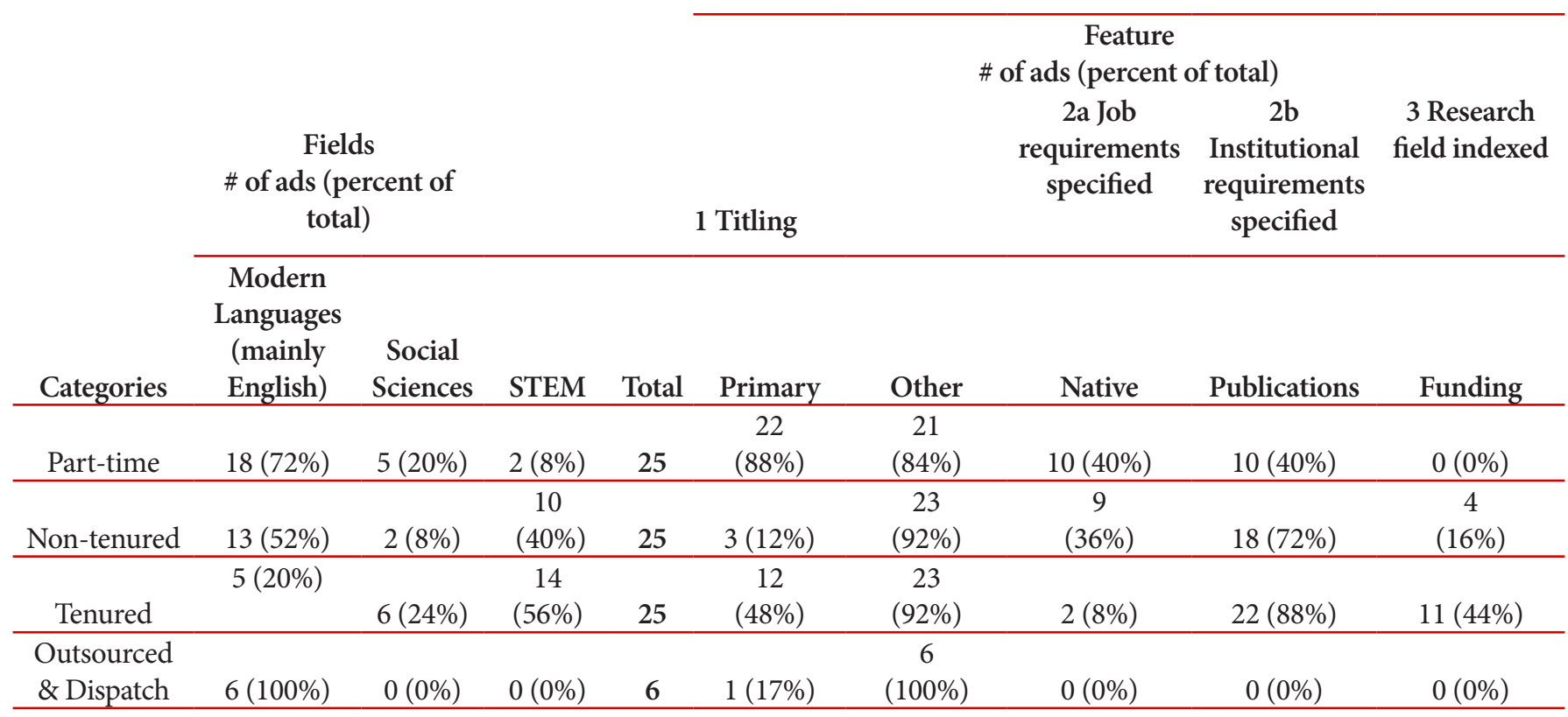

As these features evidence the intermixture of the discourse of marketization in the advertisements, we next discuss each in turn. As the main specialty fields represented in our data are STEM and modern languages, mainly English, we 
focus on these advertisements, with occasional reference to the larger dataset where appropriate.

\section{Feature 1: Titling}

Titling communicates position type and the hiring institution, with discipline or field also reflected. One finding of interest is that all the institutions, whether direct hire or dispatch, identified the organization seeking applications. In contrast, Łącka-Badura (2015) notes that in a corpus of private industry online job advertisements, 'over $40 \%$ of texts do not even reveal the employers' names" (97). Representations of Japanese higher education positions tended to be complex, signalling a wide array of applicant attributes, the most common of which were:

(1) Primary titling (38 advertisements, 47\%): "part-time" (PT 2020-0811-14); "tenure-track"; "full time" (TT 2020-08-05-1); "dispatch" (FO 2020-10-15-1). For example:

(a) "Job Opening for Part-time Instructor with native English speaker competence to teach international relations for International Career Program(ICP) [sic]" (PT 2020-08-11-14)

(b) "Announcement of Faculty Position for Tenure Track (TT) Assistant Professor (Female)" (TT 2020-08-05-1);

(c) "Dispatch University English Language Teaching Part-time Position from April 2019” (FO 2020-10-15-1)

(2) Other titling (73, 90\%), including:

(a) gender attributes: "female" (TT 2020-08-05-1; see (b) above) nativism: "native English speaker" (PT 2020-08-11-14; see (a) above)

(b) ageism: "young" (TT 2020-09-10-17), as below: "[Excellent Young Researchers]Recruitment [sic] of Senior Lecturer or Assistant Professor(Health [sic] Science Unit:Agricultural [sic] chemistry, Applied microbiology, Medical genome science, Genome biology, Metagenome, Human and animal bacterial flora, Environment \& cell transduction)"; and

(c) status: "university", “in Japan" (FO 2020-08-06-8), as below: "University Teaching in Japan! - Tokyo, Kanagawa, Chiba, Saitama, and Aichi (9/23)." (FO 2020-08-06-8) 
Primary titling is explicit in part-time adjunct advertisements (22 (88\%), Table 1) while Other titling tends to be used for the other position types, such as campus-related attributes referring to programs, such as "Transdisciplinary Science and Engineering" (NT 2020-08-14-3). English language teaching position titling (39 of 81 advertisements, 48\%) stands out for its nativism, specifically screening of applicants by nationality, with Anglophone countries preferred (21 of 39 English language advertisements, 54\%). This suggests applicants' passports are given priority, with academic and professional backgrounds less important, trends Rivers (2016) also observes. Our analysis contributes an added nuance that such native speakerism appears to be a feature of English language teaching advertisements as it is not prevalent throughout all the advertisements analysed.

The titling used appears to suggest labelling choices prioritize local institutional factors rather than sector-wide standards. Specifically, there are different tendencies in English-teaching and STEM-related positions' titling. English-teaching positions are marked with nativism, such as "Job Opening for Part-time Instructor with native English speaker competence to teach international relations for International Career Program (ICP)" (PT 2020-0811-14). Whereas tenured STEM positions exhibit ageism, as in "Excellent Young Researchers Recruitment..." (TT 2020-09-10-17) and gender; "Announcement of Faculty Position for Tenure Track (TT) Assistant Professor (Female)" (TT 202008-05-1), which are returned to in more detail in the next section.

For both position types, the term of service is prioritized through specifying contract length. The heterogeneity of direct hire university job titling contrasts with the homogeneity of dispatched job advertisements, which exhibit similar approaches to titling, with the key word "university" ( 6 of $6,100 \%$ ) featuring prominently, perhaps signifying high teacher status (despite being outsourced positions) and "in Japan" (4 of 6, 67\%), perhaps signalling to language teachers an opportunity to move from less prestigious to more prestigious work.

\section{Feature 2: Specifying the Job and Application Requirements}

Application requirements serve regulatory, informative, and interactional communicative purposes, with the following tendencies:

(1) standardization, such as nativism (Feature 1, above): "Job Opening for Part-time Instructor with native English speaker competence to teach international relations for International Career Program(ICP)" [author's emphasis] (PT 2020-08-11-14);

(2) time-limiting, or contract terms:

"The position is initially for one year, with the possibility of extension

for additional 1-2 years upon mutual consent." [ author's emphasis] (PT 2020-09-10-2); 
(3) other McJob factors, including metrification, efficiency, and multitasking

"CV (including research achievements such as publications, presentations, awards and research grants)" [author's emphasis] (NT 2020-08-03-9); and

(4) dispatched requirements:

"In order to be able to teach for [Company name] online, you would need to meet the following requirements.

- CPU: Intel Core i3 or higher (Core i5 or higher preferred)

- Memory: 4GB or higher (8GB or higher preferred)

- Internet speed: $1.5 \mathrm{Mbps}(=1500 \mathrm{Kbps})$ or faster, $3 \mathrm{Mbps}$ or faster preferred

- Operating System: Microsoft Windows 10 - November 2019 Update [1909] or newer; or Apple macOS Mojave 10.14 .6 or newer (If you are using another OS, you would be asked to check with us to confirm whether it is ok or not)

- Browser: Microsoft Edge; Google Chrome; or Apple Safari 13 or newer

- Valid and active anti-virus software

- Web camera and microphone

- Adobe Acrobat Reader DC” (FO 2021-04-09-8).

The advertisements exhibit features of standardization within disciplines. For example, nativism, such as "Native competency in English [...] is desirable" (PT 2020-08-11-8) is highlighted for English teaching positions, while STEM positions tend to require young females; "Only female" (TT 2020-08-06-3), perhaps in response to recent government initiatives (Saitou, 2011). There are several discrepancies in the full-time (TT and NT) advertisements, such as that even though gender is stressed, maternal and/or childcare support is mentioned in only one advertisement (TT 2020-09-10-11), an issue we return to in our discussion. Similarly, while 18 of 50 full-time advertisements (36\%) emphasize a desire (or requirement) to hire female researchers, these are often limited to just one or two employees (18 of 18 advertisements, 100\%).

Likewise, contract durations are different by job type and discipline. Parttime positions can be from one semester to one year (18 of 25 advertisements, $72 \%$ ) when the term of employment is specified, such as "The position is initially for one year" (PT 2020-09-10-2). On the other hand, tenure-track positions can indicate initial contract duration (4 out of 25 advertisements, 16\%) and tenure evaluation timing ( 6 out of 25 ads, 24\%) along with retirement age (8 of 25 advertisements, $32 \%$ ), such as "Three-year tenure-track appointment followed by evaluation and tenure until the mandatory retirement age of 65 if qualified" (TT 2020-08-07-1). Meanwhile, in STEM positions ageism can be explicit (4 of 14 advertisements, 29\%): "should be under 40 years old $\left({ }^{*} 1\right)$ as of April 1, 2020" 
(TT 2020-08-14-13) or implicit (4 of 14 advertisements, 29\%): "Applicants should hold a Ph.D. that was acquired from April 1, 2010 onwards" (TT-2020-10-24-1) (together 8 of 14 advertisements, 57\%).

Furthermore, McJob factors include degree requirements; a postgraduate degree, preferably a PhD (44 of 81 advertisements, $54 \%$ ), Master's or higher (15 of 81 advertisements, 19\%), with a master's less preferred (29 of 81 advertisements, $36 \%$ ); and research experience (54 of 75 advertisements, $72 \%$ ), such as " $\mathrm{Ph} . \mathrm{D}$. or the equivalent in research experience" (TT 2020-08-14-13). Also prominent in the 69 direct hire positions are requirements regarding positive teacher evaluations, lists of courses taught, number of subjects taught, and other signifiers of effectiveness (40 of 69 advertisements, 58\%), as in "Teaching Portfolio (a list of previous courses and enrolments, and if available teaching evaluations or materials that demonstrate teaching effectiveness)" (NT 2020-08-06-2). Further evidence of metrics featuring prominently in direct hiring (57 of 69 advertisements, 83\%) include requirements to evidence publication in peer-reviewed journals: "original peer-reviewed papers" (NT 2020-08-14-4) and accounting for citations, h-index and impact factor: "The number of citations and impact factor of the journal for each paper... h-index of the applicant with the name of database used" (TT 202009-10-11). In contrast, dispatched advertisements require completing online forms, with required background documents not specified in the advertisements themselves ( 6 of $6,100 \%)$.

\section{Feature 3: Research Field}

Examining how the job advertisements represent "research fields" (NT 2020-08-03-13), which appear only in direct hire advertisements and not in dispatched advertisements, there is a clear dichotomy between STEM and English. In the direct hire STEM advertisements, the research fields used tend to be based on the Japan Society for the Promotion of Science's index of research fields (72 of 75, 96\%), which are primarily used when applying for annual Kaken research funding (Yamamoto et al., 2016). For example, "Chemistry/Applied Chemistry" (TT 2020-08-06-3) corresponds to the Kaken field specification document containing seven sub-fields, including "synthetic chemistry" and "polymer chemistry" (codes 5301 to 5307, Japan Society for the Promotion of Science, 2017, p. 54). If the advertisements are ostensibly seeking candidates from outside Japan, then using these categories presents potential limitations, as generally only researchers with first-hand knowledge of Japan's Kaken research application system will be familiar with what is being indexed. Thus, applicants with experience seeking and receiving funding in Japan would be advantaged. The problematic, yet nevertheless clearly delineated research fields presented for STEM advertisements contrast with the research fields in the English language teaching advertisements, which were quite general. For example, "others" (NT 2020-08-11-22) is ambiguous concerning what research specialty is desired. 
PT positions and dispatched positions (FO) do not mention research support. Nevertheless, applicants are required to show proof of publication for every direct hire university position. Simultaneously, few non-tenured full-time adjunct positions in humanities ( 3 out of 13,12\%) note research support being available while none of the social sciences advertisements mention it, with STEM numbers somewhat better; 4 out of 10 (40\%) mention such support. The largest share of funds seems to be for tenure-track positions; 12 out of 25 (48\%).

\section{Discussion and Conclusion}

Here we first return to our research questions:

(1) How does marketisation manifest in Japan-based higher education institutions' job advertisements? How do such representations compare across disciplines?

(2) In what ways does commodification shape how the academic profession is represented?

(3) What is the impact of interdiscursivity across disciplines?

Concerning how marketization manifests in the advertisements, we find Japan-based higher education to be marketized, exhibiting the features of "McJobs" (Ritzer, 2018, p. 122) critiqued in the broader higher education literature. These include discourses of power, funding, markets of employment, research, and students as customers as well as an audit culture that reshapes, commodifies, and commercializes. How marketization necessitates 'publish or perish' exhibits through rigid requirements for promotion and tenure that require chasing numbers. Contrary to the belief that Japan occupies a special position independent of the marketization of higher education elsewhere (Brown, 2011; Mok, 2011), our analysis suggests Japan exhibits similar trends. Thus, like higher education elsewhere, the interdiscursive features of the advertisements parrot "the managerial models of private and especially public sector corporations" (Furedi, 2011, p. 1), carrying negative connotations regarding how the academic profession is represented. Specifically, within such commodified education systems, the logic of business corporations emphasizes "quick results and achievements" (Furedi, 2011, p. 1), furthering "star/sink" (Ball, 1998, p. 120) polarizations. This transforms the sector into fast-food style "academic junk food" (Bauman \& Donskis, 2013, p. 137). Thus, Japanese higher education, at least in its job advertisements, exhibits colonization by market forces.

Turning to how such representations compare across disciplines, we found the job advertisements' discourse mirrors institutional practices of competition, commodifying the academic profession through: 
(1) audit culture requiring frequent and high turnover of academic staff (in all three fields), especially through the growing number of adjunct lecturers (Childress, 2019) whose recruitment is apparently increasingly entrusted to outsourcing and dispatch companies (humanities):

"The position is initially for one year, with the possibility of extension for additional 1-2 years upon mutual consent." (PT 2020-09-10-2);

(2) requirements highlight standardized approaches across disciplines (e.g., nativism for English teaching positions and ageism coupled with gendered markers in STEM subjects):

"Native competency in English (all courses taught in English), and basic Japanese conversational ability is desirable." (PT 2020-08-11-8);

(3) rigidness and inaccessibility of research funding for certain disciplines (humanities and social sciences); while research in STEM disciplines is funded selectively:

"B)Research [sic] subsidy of $¥ 200,000$ [approximately 1,800 USD] will be paid. This is intended to be spent on, for example, books, stationery, attendance at conferences etc." (NT 2020-08-11-10); and

(4) intense quantification of conditions for upward career movement that require indexed, peer-reviewed publications regardless of whether research opportunities are supported (STEM) or not (humanities and social sciences):

"(2) A list of research achievements (Please classify publications into the following categories: A. Original papers, B. Review/tutorial papers, C. International conferences (with full paper review), D. International conferences (etc.), E. Domestic conferences, F. Books, G. Patents, H. Awards, I. Invited talks, J. Grants, K. Academic service, and L. Misc.)

(3) - PDF files of major original peer-reviewed papers (up to 3)." (NT 2020-08-14-4)

Regarding how commodification shapes representations of the academic profession, our study supports the conclusion that Japan-based universities have "become a highly irrational place" (Ritzer, 2018, p. 175), with universities pressured through constant competition. Such pressure to compete forces teaching universities to satisfy their student-customers while research universities aim for peer-reviewed publications in English. Within the advertisements analysed, there were also apparent shortcuts intended to achieve these goals in shrinking markets. For example, advertisements for English language teaching positions sought idealized exotic "native" speakers. In addition, the oversupplied market of academics faces survival pressure within the limited market of institutional and external research funding. We also document Japan's academic job market including part-time English teachers outsourced to private businesses, further 
evidencing fastfoodization of the academic profession. Like ready-made meals, dispatch companies catalogue applicants into parcels delivered without the need for universities to directly involve themselves in hiring, training, or quality control, and absent academic creativity and autonomy for the dispatched workers.

Concerning the impact of interdiscursivity across disciplines in the job advertisements, they are universal in presenting lip service to ideals and standards that are not necessarily compatible with a marketized higher education landscape. For example, while some STEM advertisements explicitly solicit applications from female researchers, only one explicitly specifies childcare availability. However, maternity/paternity leave and the other kinds of support necessary to foster a gender inclusive work environment are not explicitly mentioned. At the same time, in the humanities and social sciences, while the availability of research support is not specified, requirements to qualify for the positions advertised and to attain promotion once in position include publication. This is not to claim that support is not available to those in position in all cases; the availability of such support could be implicitly understood and therefore excluded from the advertisements. Such a circumstance could reflect Japan as a high-context culture in line with Hall (1976), where few details need to be supplied. This resonates with Muller and Skeates (forthcoming), who note that such advertisements require applicants to submit proof of an ability to research but tend not to specify what and how much research and how many publications are expected.

Further, the advertisements are ostensibly seeking applications from researchers educated and (currently) based outside of Japan. However, the STEM advertisements represent research funding in a Japan-centric way, centring around the Kaken funding system, which is likely opaque to those not already familiar with it. Thus, when ideals of inclusivity encounter the forces of efficiency and quantification in marketized higher education, inclusivity loses out to efficiency and quantification.

Concerning our investigation's limitations, we examined a convenience sample of job advertisements in English collected over a short span of time. More systematic data collection might have yielded more insightful findings. However, our focus on discussing how broader tensions are represented within Japan-based higher education helps mitigate this. Our analysis suggests that across disciplines the academic profession, traditionally tuned towards upward mobility and distinctive for its own codes and procedures, is currently struggling for survival amid forces of marketization and neoliberalization. Ideologies and policies are rarely simply aped (Ball, 1998), with national and local contexts in play, such as using Japan-specific identifiers to indicate preferred research specialisms (local) and efforts to recruit women (national). CDA (Fairclough, 2012), in this instance, facilitated studying and explaining 'social wrongs,' understood as facets of 'social systems, forms or orders that are detrimental to human well-being' (p. 13). We scrutinized how the professional and social practices of Japan-based higher education are (re)created by marketized discourses. This application of CDA to the academic profession in Japan represents one contribution of our 
study, as Japan-based higher education remains relatively unexplored using such methods. Much of the literature to date examines data from primary sources such as surveys (Arimoto, 2011); statistical data produced by MEXT and other governmental agencies (Huang, 2015); and reports and recommendations (Saitou, 2011). While such publications provide insights into policy, they neglect to discuss tensions and issues surrounding the philosophies underpinning Japanbased higher education's discourse. For example, our review demonstrates how Japan-based higher education is romanticized in such literature, with faculty depicted as largely concentrating on research first and teaching second. However, our examination of the job advertisements presented here shows the reality is different from such romanticized depictions, with metrification and competition prevalent and the availability of support resources apparently limited. In conclusion, we found Japan-based higher education subject to the same forces of marketization affecting the academic profession more broadly, albeit with local affordances. These findings engage and further larger discussions of the marketization of the academic profession.

\section{Disclosure Statement}

The authors have no conflicts of interest to disclose.

\section{References}

Arimoto, A. (2011). Effects of changing governance and management on the academic profession. In W. Locke, W. Cummings \& D. Fisher (Eds.), Changing governance and management in higher education (pp. 281-319). Dordrecht: Springer. https:// doi.org/10.1007/978-94-007-1140-2_14

Askehave, I. (2007). The impact of marketization on higher education genres: The international student prospectus as a case in point. Discourse Studies, 9, 723-742. https://doi.org/10.1177/1461445607082576

Askehave, I. (2010). Communicative leadership: A discourse analytical perspective on the job advertisement. Journal of Business Communication, 47(3), 313-345. https://doi.org/10.1177/0021943610365310

Ball, S. (1998). Big policies/small world: An introduction to international perspectives in education policy. Comparative Education, 34, 119-130. https:// doi.org/10.1080/03050069828225

Bauman, Z., \& Donskis, L. (2013). Moral blindness: The loss of sensitivity in liquid modernity. Cambridge, UK: Polity.

Bauman, Z. (2000). Liquid modernity. Cambridge, UK: Polity.

Bauman, Z. (2007). Consuming life. Cambridge, UK: Polity.

Becher, T., \& Trowler, P. (2001). Academic tribes and territories: Intellectual enquiry and the cultures of disciplines (2nd ed.). Milton Keynes: Open University Press.

Brown, R. (2011). The march of the market. In M. Molesworth, R. Scullion, \& E. Nixon (Eds.), The marketisation of higher education and the student as consumer (pp. 11-25). London: Routledge.

Childress, H. (2019). The adjunct underclass: How America's colleges betrayed their faculty, their students, and their mission. Chicago: University of Chicago Press. https://doi.org/10.7208/chicago/9780226496832.001.0001 
de Wit, H. (2009). Internationalisation of higher education in Europe and its assessment, trends and issues. The Hague: NVAO.

Fairclough, N. (1993). Critical discourse analysis and the marketization of public discourse: The universities. Discourse and Society, 4, 133-168. https://doi. org/10.1177/0957926593004002002

Fairclough, N. (1995). Critical discourse analysis: The critical study of language. London: Longman.

Fairclough, N. (2012). Critical discourse analysis. In J. Gee \& M. Handford (Eds.), The Routledge handbook of discourse analysis (pp. 9-21). London: Routledge.

Feng, D. (2019). Interdiscursivity, social media and marketized university discourse: A genre analysis of universities' recruitment posts on WeChat. Journal of Pragmatics, 143, 121-134. https://doi.org/10.1016/j.pragma.2019.02.007

Foucault, M. (1972). The archaeology of knowledge and the discourse on language. London: Tavistock.

Furedi, F. (2011). Introduction to the marketisation of higher education and the student as consumer. In R. S. M. Molesworth \& E. Nixon (Eds.), The Marketisation of Higher Education and the Student as Consumer (pp. 1-9). London: Routledge.

GaijinPot. (2019). GaijinPot Jobs. https://jobs.gaijinpot.com/

Gunn, A. C., Berg, D., Hill, M. F., \& Haigh, M. (2015). Constructing the academic category of teacher educator in universities' recruitment processes in Aotearoa, New Zealand. Journal of Education for Teaching, 41(3), 307-320. https://doi.org/1 0.1080/02607476.2015.1041288

Hadley, G. (2015). English for academic purposes in neoliberal universities: A critical grounded theory. Dordrecht: Springer. https://doi.org/10.1007/978-3-319-104492

Hall, E. (1976). Beyond culture. New York: Anchor Press.

Hall, J. (1998). Cartels of the mind: Japan's intellectual closed shop. New York: Norton.

Huang, F. (2014). Challenges for higher education and research: A perspective from Japan. Studies in Higher Education, 39(8), 1-11. https://doi.org/10.1080/0307507 9.2014.949535

Huang, F. (2015). Changes in Japanese academics' teaching and research, 1992-2011. Studies in Higher Education, 40(10), 1-10. https://doi.org/10.1080/03075079.201 5.1060705

Japan Science and Technology Agency. (2020). jRec-IN Portal. https://jrecin.jst.go.jp/

Japan Society for the Promotion of Science. (2017). Application Procedures for Grants-in-Aid for Scientific Research-KAKENHI. http://www.gakuin.otsuma. ac.jp/jyosei/joseikin/kakenhi/koubo/2017\%20koubo(JSPS)(suishin\%20etc)_e. $\mathrm{pdf}$

Indeed. 2020. Indeed. https://jp.indeed.com/

JALT Publications. (2020). Job listings. https://jalt-publications.org/tlt/departments/ career-development-corner/jobs

Kress, G. (2012). Multimodal discourse analysis. In J. Gee \& M. Handford (Eds.), The Routledge Handbook of Discourse Analysis (pp. 35-51). London: Routledge.

Kuwayama, T. (2017). Japanese anthropology, neoliberal knowledge structuring, and the rise of audit culture: lessons from the academic world system. Asian Anthropology, 16(3), 159-171. https://doi.org/10.1080/1683478X.2017.1346891 
Łącka-Badura, J. (2015). Recruitment advertising as an instrument of employer branding: A linguistic perspective. Cambridge: Cambridge Scholars Publishing.

Lowrie, A., \& Hemsley-Brown, J. (2011). On the marketisation and marketing of higher education. Journal of Marketing Management, 27(11-12), 1081-1086. https://doi.org/10.1080/0267257X.2011.614733.

McCrostie, J. (2010). The right stuff: hiring trends for tenured university positions in Japan. The Language Teacher, 34(5), 31-35. https://doi.org/10.37546/ JALTTLT34.5-2

Mok, K. (2011). Liberalization of the privateness in higher education: Funding strategies, changing governance and policy implications in Asia. In P. Teixeira \& D. Dill (Eds.), Public vices, private virtues? (pp. 19-47). Sense Publishers. https:// doi.org/10.1007/978-94-6091-466-9_2.

Molesworth, M., Scullion, R., \& Nixon, E. (Eds.). (2011). The marketisation of higher education and the student as consumer. London: Routledge. https://doi. org/10.4324/9780203842829.

Muller, T. \& Skeates, C. (forthcoming). Institutionality in Anglophone and Japan University Job Advertisements: A Critical Discourse Analysis of Representations of Academic Work. In Y. Porsché, R. Scholz, \& J. N. Singh (Eds.), Institutionality and the Making of Political Concerns: Empirical Analyses of Discursivity and Materiality. Palgrave Macmillan.

Nuttall, J., Brennan, M., Tuinamuana, K. \& Cameron, L. (2013). Lost in production: The erasure of the teacher educator in Australian university job advertisements. Journal of Education for Teaching: International Research and Pedagogy, 3(39), 329-343. https://doi.org/10.1080/02607476.2013.799849.

Pack, J. (2018). How the neoliberalization of academia leads to thoughtlessness: Arendt and the modern universit. Lanham: Lexington Books.

Pekkola, E., Kivistoe, J., Kohtamaeki, V., Cai, Y., \& Lyytinen, A. (2018). Theoretical and methodological perspectives on higher education management and transformation. Tampere: Tampere University Press.

Reilly, J., Turcan, R., \& Bugaian, L. (2016). The challenge of university autonomy. In R. Turcan, J. Reilly, \& L. Bugaian (Eds.), (Re)discovering university autonomy: The global market paradox of stakeholder and educational values in higher education (pp. 3-26). New York: Palgrave Macmillan. https://doi.org/10.1057/9781137388728_1.

Ritzer, G. (2018). The McDonaldization of society: Into the digital age (9th ed). London: Sage. https://doi.org/10.1002/9781405165518.wbeosm001.pub2.

Rivers, D. (2013). Institutionalized native-speakerism: Voices of dissent and acts of resistance. In S. Houghton \& D. Rivers (Eds.), Native-speakerism in Japan: Intergroups dynamics in foreign language education (pp. 75-91). Clevedon: Multilingual Matters. https://doi.org/10.21832/9781847698704-009.

Rivers, D. (2016). Employment advertisements and native-speakerism in Japanese higher education. In F. Copland, S. Garton, \& S. Mann (Eds.), LETs and NESTs: Voices, views and vignettes (pp. 79-100). London: British Council.

Saitou, Y. (2011). Higher education in Japan. https://www.nier.go.jp/English/ educationjapan/pdf/201109HE.pdf.

Teichler, U. (2004). The changing debate on internationalisation of higher education. Higher Education, 48(1), 5-26. https://doi.org/10.1023/ B:HIGH.0000033771.69078.41. 
Teichler, U., Arimoto, A. \& Cummings, W. (2013). The changing academic profession: Major findings of a comparative survey. Dordrecht: Springer. https://doi. org/10.1007/978-94-007-6155-1.

Turner,J.(2011).Languageintheacademy:Culturalreflexivityandinterculturaldynamics. Clevedon: Multilingual Matters. https://doi.org/10.21832/9781847693235.

Watanabe, S., Murasawa, M., \& Abe, Y. (2013). Internal staff allocation and the changing workload of Japanese professoriate: A multilevel statistical analysis with simulations. US Berkeley, Research and Occasional Papers Series, 1-11.

Wieczorek-Szymanska, A. (2020). Gender diversity in academic sector - case study. Administrative Sciences, 10(3), 1-20. https://doi.org/10.3390/admsci10030041

Wodak, R. (1996). Disorders of discourse. London: Longman.

Xiong, T. (2012). Discourse and marketization of higher education in China: The genre of advertisements for academic posts. Discourse \& Society, 23(3), 318-337. https://doi.org/10.1177/0957926511433786.

Yamamoto, S. (2012). Higher education reforms in Japan: Changing relationship between government and universities. In H. Schuetze \& G. Mendiola (Eds.), State and market in higher education reforms trends, policies and experiences in comparative perspective (pp. 199-209). Dordrecht: Sense Publishers.

Yamamoto, Y., Imai, K., \& Taketo, T. (2016). Who search for research grant for what and when? Information Engineering Express, International Institute of Applied Informatics, 2, 11-21.

Yonezawa, A., Akiba, H., \& Hirouchi, D. (2009). Japanese university leaders' perceptions of internationalization. Journal of Studies in International Education, 13(2), 125-142. https://doi.org/10.1177/1028315308330847.

Recebido em: 29/07/2021

Aceito em: 13/12/2021 


\section{APPENDIX 1}

Sample Job Advertisement PT 2020-08-11-8 (anonymized)

\begin{tabular}{|c|c|c|}
\hline Data number & \multicolumn{2}{|l|}{ D120071781 } \\
\hline Date of publication & \multicolumn{2}{|l|}{$2020 / 07 / 29$} \\
\hline Date of update & \multicolumn{2}{|l|}{$2020 / 07 / 29$} \\
\hline Title & \multicolumn{2}{|c|}{ [University Name], Department of Japanese, Part-time English Lecturer } \\
\hline Institution & \multicolumn{2}{|c|}{ [University Name] } \\
\hline $\begin{array}{l}\text { URL of institution or } \\
\text { department }\end{array}$ & \multicolumn{2}{|l|}{$[\mathrm{URL}]$} \\
\hline Department & \multicolumn{2}{|c|}{ Department of Japanese, Faculty of Foreign Languages } \\
\hline Institution type & \multicolumn{2}{|c|}{ Private university } \\
\hline Job posting URL & \multicolumn{2}{|c|}{$[\mathrm{URL}]$} \\
\hline $\begin{array}{l}\text { Content of job infor- } \\
\text { mation }\end{array}$ & \multicolumn{2}{|c|}{$\begin{array}{l}\text { [University Name], Department of Japanese, is seeking candidates for a part-time } \\
\text { teaching position for the } 2021 \text { academic year, beginning April 1st, 2021. It involves } \\
\text { teaching three } 90 \text {-minute classes once a week, either on Monday or Wednesday at } \\
\text { [Name] Campus, [City], for the following three courses. } \\
\text { a) English Communication Skills, } \\
\text { b) Integrated English Skills, including TOEIC Test Preparation, } \\
\text { c) Content Area Studies. } \\
\text { The classes are taught from the second to fourth period; 2nd period 10:55-12:25, 3rd } \\
\text { period 13:15-14:45, and 4th period 15:00-16:30. } \\
\text { 1. Subjects to be taught: third-year or fourth-year English } \\
\text { 2. Period of appointment: one year (April 1, 2021 - March 31, 2022.) } \\
\text { 3. Number of positions available: one } \\
\text { 4. Rank of appointment: part-time lecturer }\end{array}$} \\
\hline \multirow{6}{*}{ Research field } & Area & Humanities \\
\hline & $\begin{array}{l}\text { 1. } \begin{array}{l}\text { Disci- } \\
\text { pline }\end{array} \\
\end{array}$ & Linguistics \\
\hline & Area & Humanities \\
\hline & $\begin{array}{l}\text { Disci- } \\
\text { pline }\end{array}$ & Literature \\
\hline & Area & Humanities \\
\hline & $\begin{array}{l}\text { Disci- } \\
\text { pline }\end{array}$ & All Humanities \\
\hline Job type & \begin{tabular}{|l|l|}
1. & Lecture \\
\end{tabular} & (part-time) \\
\hline Employment status & \multicolumn{2}{|c|}{ Part-time(Nontenured) } \\
\hline Work location & \multicolumn{2}{|c|}{ [Name] district - [City] } \\
\hline
\end{tabular}




\begin{tabular}{|c|c|c|c|}
\hline Qualifications & \multicolumn{3}{|c|}{$\begin{array}{l}\text { (1) at least an MA in TESOL, TEFL, English linguistics, or other relevant fields } \\
\text { (2) At least one year teaching experience at a college level at the time of employment. } \\
\text { (3) Native competency in English (all courses taught in English), and basic Japanese } \\
\text { conversational ability is desirable. } \\
\text { (4) Citizenship will not be considered in the selection process. } \\
\text { (5) If English is not the candidate's native language, then level of English proficiency } \\
\text { sufficient for pedagogical purposes; if Japanese is not the candidate's native language, } \\
\text { then level of Japanese proficiency sufficient for administrative purposes } \\
\text { (6) The ability to teach online if needed. }\end{array}$} \\
\hline Compensation & \multicolumn{3}{|c|}{$\begin{array}{l}\text { 1.Terms of compensation } \\
\text { (1) Salary: determined, based on qualifications and experience, in accordance with } \\
\text { standard regulations for [University Name]. } \\
\text { (2) Commuting expense: offered according to the university regulations. } \\
\text { (3) Retirement benefits: not offered. } \\
\text { 2.Terms of employment } \\
\text { (1) Workplace will be the Itabashi campus of [University Name]. } \\
\text { (2) Classes taught either on Monday or Wednesday from the second to fourth period; } \\
\text { 2nd period 10:55-12:25, 3rd period 13:15-14:45, and } 4 \text { th period 15:00-16:30. }\end{array}$} \\
\hline Application period & \multicolumn{3}{|c|}{ 2020/09/18 Deadline for receipt } \\
\hline $\begin{array}{l}\text { Application } \\
\text { /selection } \\
\text { /notification of result } \\
\text { /contact details }\end{array}$ & \multicolumn{3}{|c|}{$\begin{array}{l}\text { 1.Materials to be submitted: } \\
\text { (1) Curriculum vitae (in any format, in English or Japanese) } \\
\text { (2) List of research publications (in any format) } \\
\text { (3) One copy of one or two representative publications } \\
\text { (4)A copy of the diploma for the highest relevant degree } \\
\text { 2. How to apply: please submit your application materials in PDF format (desirably } \\
\text { compressed in a single zip file) at [email] } \\
\text { 3. Application deadline: September 18, Friday, } 2020 . \\
\text { 4. Selection schedule: } \\
\text { (1) Round one: document screening } \\
\text { (2) Round two: interviews (in-person or remote; scheduled for late September or Oc- } \\
\text { tober). Candidates who pass round one will be invited, by email, to interview. Recruit- } \\
\text { ment will continue until the position is filled. } \\
\text { 5. Address any inquiries to: [Name] ([email]) } \\
\text { If you have not received an acknowledgement of your application within ten days of } \\
\text { submitting it, you should also contact [Name] at [email] }\end{array}$} \\
\hline \multirow{4}{*}{ Online Submission } & \multicolumn{3}{|c|}{ Online Submission with all application documents is available. } \\
\hline & JREC-IN Portal web application & Not available & \\
\hline & Email Application & Accept & \\
\hline & $\begin{array}{l}\text { Recruiting Institution's } \\
\text { Web application system }\end{array}$ & Not available & \\
\hline & \multicolumn{3}{|c|}{$\begin{array}{l}\text { Additional notes regarding period of appointment: } \\
\text { - Upon completion, contracts may be renewed for up to one year based on the follow- } \\
\text { ing considerations: } \\
\text { 1) Anticipated number of course offerings and student registration for the subsequent } \\
\text { academic year or semester } \\
\text { 2) Performance evaluation } \\
\text { 3) Aptitude and suitability } \\
\text { - No contract may be renewed beyond the academic year in which the instructor } \\
\text { reaches the age of } 70 \text {. }\end{array}$} \\
\hline
\end{tabular}

